\title{
Etnopedagogy Approach to Science Learning in Sdn 50 City of Ternate Based on The Local Wisdom of Rempah North Maluku
}

\author{
Said Hasan ${ }^{\mathrm{a} *}$, Abdu Mas'ud ${ }^{\mathrm{b}}$, Sundari ${ }^{\mathrm{b}}$ \\ ${ }^{a}$ Departement Biology Education of Postgraduate, Universitas Khairun, Ternate, Indonesia \\ ${ }^{\mathrm{b}}$ Faculty of Teacher Training and Education, Universitas Khairun, Ternate, Indonesia \\ first.author@email.com*; second.author@email.com; third.author@email.com; \\ *Corresponding author
}

\begin{tabular}{l}
\hline \hline Article Info \\
\hline Article history: \\
Received Aug 30, 2021 \\
Revised Oct 28, 2021 \\
Accepted Oct 29, 2021 \\
\hline
\end{tabular}

\section{Keywords:}

Ethnopedagogy

Cloves

Spices

Science

Ternate

\begin{abstract}
Local wisdom-oriented learning in elementary schools in the city of Ternate has not been implemented optimally. In general, schools have implemented thematic learning that should contain local wisdom. Ethnopedagogy is the actualization of learning oriented to the cultivation of local wisdom values. Ethnopedagogic aproach in elementary schools need to be implemented through strategies and innovative learning media that are able to attract students' attention to understand and apply local wisdom. This study aims to integrate Cloves as an identity flora in North Maluku in the implementation of an ethnopedagogic aproach at elementary schools in Ternate. This study uses a qualitative approach with a mixed method of research instruments consisting of observation sheets and questionnaires. Data analysis technique with concurrent triangulation strategy. The results showed that the ethnopedagogical approach implemented through learning activities using cloves as a spice study object in North Maluku was an effective alternative to local wisdom-based learning applied in elementary schools in Ternate city. Through the integration of cloves in an ethnopedagogical approach, it can improve scientific literacy skills and students' learning motivation. This study recommends that the ethnopedagogical approach can be implemented with innovative learning activities based on local wisdom.
\end{abstract}

This is an open access article under the CC BY-SA license.

\section{Introduction}

The 21st century is marked by the rapid development of science and technology in the fields of life in society, especially information and communication technology. The rapid development of science in the 21st century requires humans to work hard to adapt to all aspects of life. One of the keys to success in addressing the challenges of the 21 st century is "science literacy". Science has potential and a role in preparing quality human resources to face the era of industrialization and globalization. This potential will be realized if science education is able to produce students who are skilled in their fields and have the ability to think logically, creatively, and able to solve problems, be critical, master technology and be able to adapt to changes and developments of the times (Nofiana \& Julianto, 2018; Wijaya, et al., 2016). 
Currently the values of local cultural wisdom if not maintained will experience a process of extinction due to the influence of globalization. One of the efforts to maintain it is through the use of local resources and culture in the learning process in schools. Science as a lesson that plays an important role in developing scientific literacy is expected to be able to empower and make the best use of existing local resources and culture (Maulidia, et al. 2018; Syaban, \& Wilujeng, 2016); Tilaar, 2002). Science learning in elementary schools is expected to develop students' abilities to live in society. At this time, educators are needed who have sufficient understanding of local cultural values in addition to their ability to understand the subject matter.

Cloves as identity flora are native plants and superior commodities of spices in North Maluku. Cloves, nutmeg, Kenari, and cinnamon are the favorite of spices in Maluku. Historically, these spices grew and lived wildly, especially in Tidore, Ternate and Makian, so these islands were called the spice island. People in these islands only found out after the arrival of Makassar, Javanese, Chinese, and Arab traders who bought spices by exchanging goods such as household utensils and other necessities.

Natural Science is one of the subjects in elementary school that is important because it is a provision for students in facing various challenges in the global era. The approach and learning strategy chosen as a way of learning science must be able to prepare students to have good competence and literacy in science and technology, be able to think logically, critically, creatively, argue correctly, be able to communicate and collaborate (Holbrook 2009; Yuliati, 2017). In general, elementary school students in Ternate City have multiethnic characteristics with island coastal areas. Elementary school students in Ternate City come from various ethnic groups, both natives of North Maluku and migrants from outside. Culture, language, habits and communication patterns are one of the main factors that need special attention in developing and improving the quality of education in the 21 st century.

Ethnopedagogy is the actualization of learning oriented to the cultivation of local wisdom values (Putra, 2017; Oktavianti \& Ratnasari, 2018; Rahmawati, 2020). As an approach, ethnopedagogy in elementary schools needs to be implemented with innovative learning strategies and media that are able to attract students' attention to understand and apply local wisdom. Ethnopedagogic-oriented learning is very important considering that North Maluku is an archipelagic country and a diverse region consisting of various tribes and ethnicities with different cultures. If ethno-pedagogical-oriented learning is not applied early on, then in the future globalization and rapid technological developments can shift local wisdom in society. This shift occurs because there is no clear boundary between local culture and foreign culture. This condition clearly shows that education in Indonesia, especially in North Maluku, needs to apply learning oriented to local wisdom, one of which is by utilizing issues or cloves as the leading spice in North Maluku. The issue of cloves is used as a tool or teaching material for science learning in elementary schools. The strategy applied in this research is problem-based learning. This study aims to integrate Cloves as an identity flora in North Maluku in the application of an ethnopedagogic approach in elementary schools in Ternate City.

\section{Method}

This research was conducted on 4th grade students at SDN 50 Ternate City from August to October 2020. A mixed method approach that combines qualitative and quantitative approaches (Rachman, 2015; Sugiyono, 2014). Data collection and analysis techniques in this study used concurrent triangulation, to produce substantive and validated findings. The 
data was collected using observation techniques, limited interviews and documentation of the implementation of learning with a Problem Based Learning strategy that integrates the latest clove issues as teaching materials developed in this study.

The observation technique in this study was participatory observation of students and teachers in science learning with an ethnopedagogical approach based on the issue of cloves as spices in North Maluku. Participatory observation, researchers used a rating scale from raw data obtained in the form of numbers and then interpreted qualitatively (Sugiyono, 2015; Sularso, 2015). The limited interview method in this study was given to students with the aim of knowing the extent to which students' ability to develop conceptual understanding with an integrated ethnopedagogic approach uses the content of clove local wisdom in North Maluku.

Documentation in this study is expected to learn to read and record what is implied and stated in the document, so that it can strengthen research data. The data analysis technique uses quantitative data analysis and qualitative data with the aim of quantifying qualitative data so that it can be analyzed quantitatively where quantitative data is based on assumptions and assessments expressed by quantitative data. Quantitative data analysis used descriptive statistical analysis techniques while qualitative data analysis used interactive analysis models.

The design learning goals are determined based on the basic competencies of thematic learning curriculum 2013 (knowledge) which are presented in Figure 1 below.

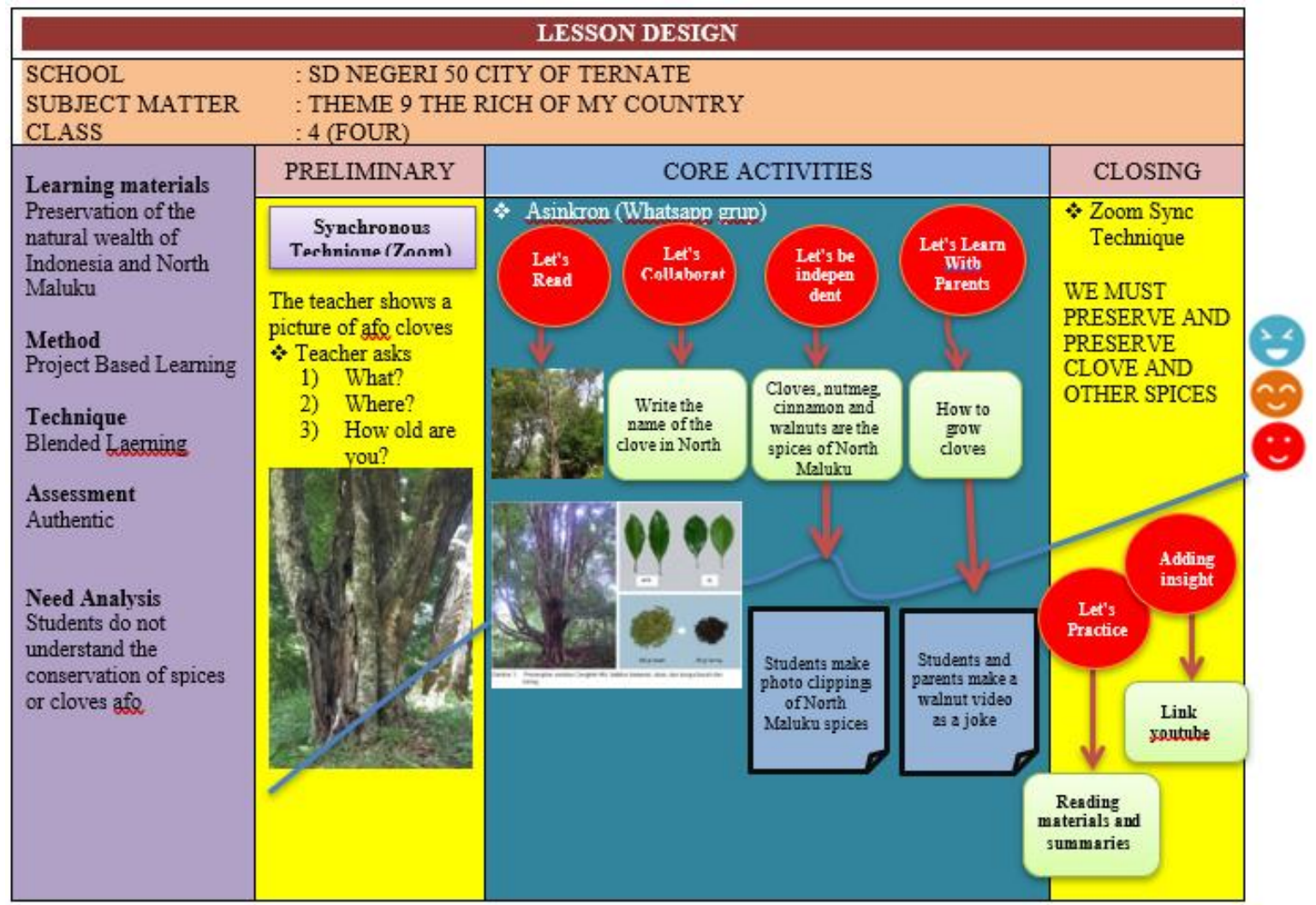

Figure 1. Lesson Design for Science Learning with an Ethnopedagogical Approach 


\section{Results and Discussion}

Data on the Implementation of Ethnopedagogical Principles in Science Learning at SDN 50 Ternate City

Data on the implementation of the ethnopedagogic approach in science learning at SDN 50 Ternate City was obtained based on the results of classroom observations. The results of the data analysis came from the student assignment documents during the learning of several aspects of observing the application of the pedagogic approach. The results of data analysis are converted into percent (\%). A description of the ethnopedagogic approach can be seen in Figure 2 below:

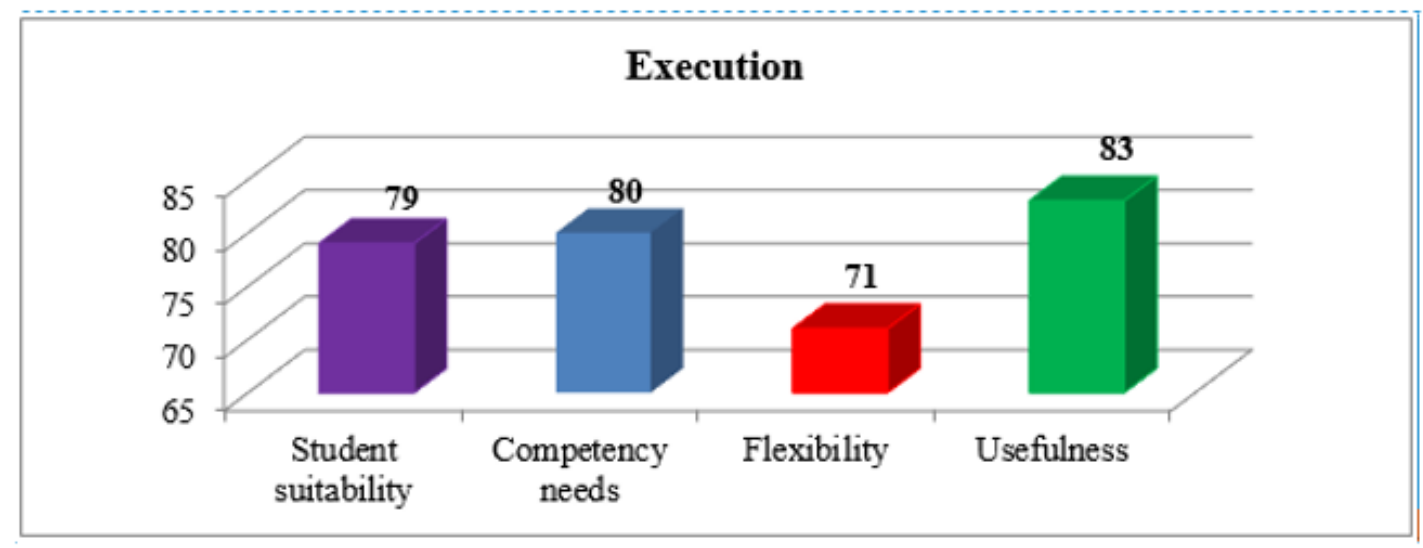

Figure 2. Implementation of ethnopedagogical principles in science learning at SDN 50 Ternate city

Based on Figure 2, it can be seen that the highest ethnopedagogical approach implemented in science learning at SDN 50 Ternate City are the benefits for the national to global interests from the ethnopedagogical approach used in learning by $83 \%$ and the principle of flexibility of type, form and time is a principle with implementation. lowest at $71 \%$. Based on these principles, it can be seen that the implementation of the ethnopedagogical approach in science learning at SDN 50 Ternate City is in accordance with ethnopedagogic approach.

Data on Student Responses to Knowledge of Local Resources Cloves as Spices in North Maluku

The data from limited interview to the students of SDN 50 Ternate City with the interview guide getting student responses related to student responses after carrying out learning with an ethnopedagogical approach. Using a Likert scale, qualitative data was converted into quantitative data. Quantitative data scores are converted into percent (\%), then described based on the results of data analysis. The description of the data recapitulation is presented in Figure 3 below 


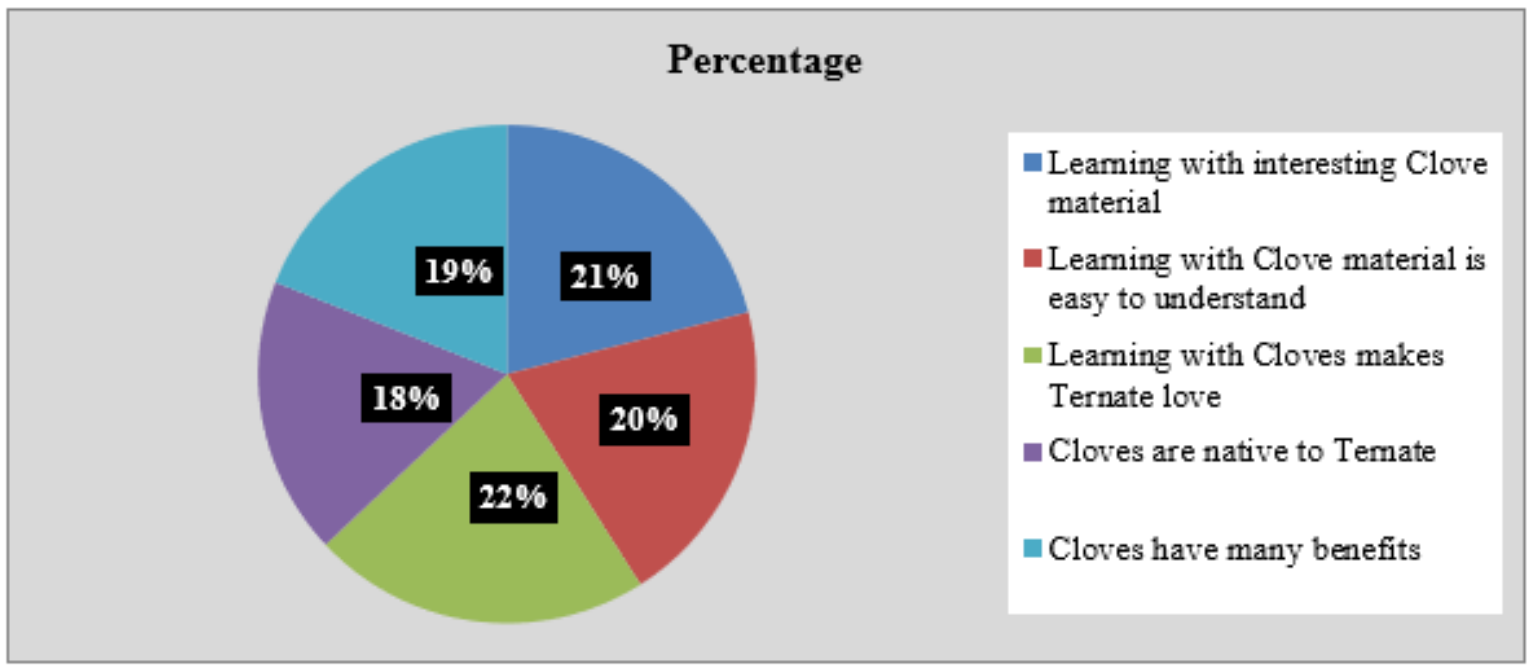

Figure 3. Percentage of Student Responses after Implementing etnopedagogical approach at SDN 50 Ternate City.

Based on Figure 3, it can be seen that as many as $22 \%$ of students stated that learning with clove teaching materials made students like Ternate as the highest response. Based on the data above, it is known that elementary school students feel happy and motivated during learning to use cloves, but from Figure 3 above it is also known that most students do not understand that cloves are native to the island of Ternate.

The integration of clove issues in the implementation of the ethnopedagogical approach in science learning for students can provide knowledge about cloves and local cultural identity in North Maluku. Students' knowledge of cloves as spices is in the sufficient category. As many as $18 \%$ of students responded that clove is a native plant of Ternate, cloves have many benefits. Furthermore, from the results of limited interviews, it was found that students felt motivated when learning to use media and teaching materials on the issue of cloves as spices. However, students' knowledge of cultural history is still not optimal, so this can be optimized by developing a learning model with an ethnopedagogic approach that raises local cultural issues in learning, especially science in elementary schools.

One of the subjects in elementary school that plays a significant role in developing cultural literacy is Natural Sciences. The main purpose of learning science in elementary schools is to instill scientific literacy competencies in life and use these competencies to solve problems. That is, the success of learning science in elementary schools will lead students to situations of having a critical attitude and being able to find solutions to existing problems. If the values of local cultural wisdom are not maintained and maintained, it is feared that they will gradually experience a process of extinction due to the influence of globalization. One of the efforts to maintain it is through the use of local culture in the learning process at school.

Ethnopedagogy is an alternative approach that reflects local content in learning or better known as local wisdom-based learning. In general, local wisdom has characteristics and functions, namely; 1) as a marker of the identity of a community, 2) as an adhesive element of social cohesion, 3) as a cultural element that grows from below, exists and develops in society, is not an element that is forced from above, 4) serves to provide a color of togetherness for certain communities, 5) can change the mindset and reciprocal relationships of individuals and groups by putting them on a common ground, 6) able to encourage the establishment of togetherness, appreciation and a common mechanism to defend themselves 
from the possibility of disturbance or destruction of group solidarity as a whole and integrated community (Utari \& Degeng, 2017).

This study uses four principles of learning local wisdom and thematic curriculum 2013 using learning media in the form of clove plants as spices in North Maluku. Local wisdom developed in learning uses four principles, namely; 1) conformity with the development of students, 2) the need for competence, 3) flexibility in the type, form, and timing of the implementation, and 4) usefulness for the national interest in facing global challenges.

Ethnopedagogy which is reflected in local wisdom applied in this study is intended to introduce and preserve local culture in students so that students are expected to understand and love North Maluku spices more as their local wisdom. This expectation is adjusted to the study of Sartini (2010); Kun, (2013) which states that local wisdom is a local (local) idea that is wise, full of wisdom, of good value that is embedded and followed by community members. The study of local wisdom needs to be instilled from an early age so that students are able to face global challenges.

The concept of local wisdom implemented in this study is associated with the local wisdom of the island of Ternate which includes the study of the spice culture in North Maluku. Cultural studies according to Koentjaraningrat, (1974); Kistanto, (2015) includes systems of religion, society, knowledge, language, arts, livelihoods, technology systems and equipment.

Ternate Island is part of the province of North Maluku, which produces spices in the world. This local wisdom should be preserved and passed down from generation to generation. In this case, the role of education is felt to be important to introduce early on to students the local wisdom of the region. The teacher as the main facilitator in education must provide a portion of the ethnopedagogic approach with local wisdom in each subject.

The results of this study can be used as a reference for developing research at different levels of education or in different subjects so that the implementation of learning based on local wisdom can be sustainable. The purpose of this research with the application of ethnopedagogy in accordance with the design lesson goals achieved is that students are proud of the local wisdom of North Maluku spices. The results of the application of the clove integration ethnopedagogic approach in science learning to fourth grade students at SDN 50 Ternate City indicate that the goal of integrated thematic learning design using the cultural identity of the North Maluku Spice Island as Ternate Cultural Wisdom shows that students are proud of Ternate cultural wisdom needs to be improved.

The ethnopedagogic approach gives the impression given to students in learning using cloves as a North Maluku spice in thematic learning, showing that during the implementation of learning, they feel learning with tension and theory but learning real life every day and comfortable. However, when the teacher provides follow-up in the form of final reflection activities, students are only able to respond and answer the history and benefits of cloves correctly, so it can be concluded that there is a need for stimulation of the integration of local culture in learning in schools through an ethnopedagogic approach.

Documentation data of research on the implementation of the ethnopedagogical approach in 4th grade students of SDN 50 Ternate City on Theme 9 The richness of my country with the integration of the issue of cloves as a spice in North Maluku is a description of the implementation of learning with an ethnopedagogical approach. The following documentation of this research can be seen in Figure 4. 


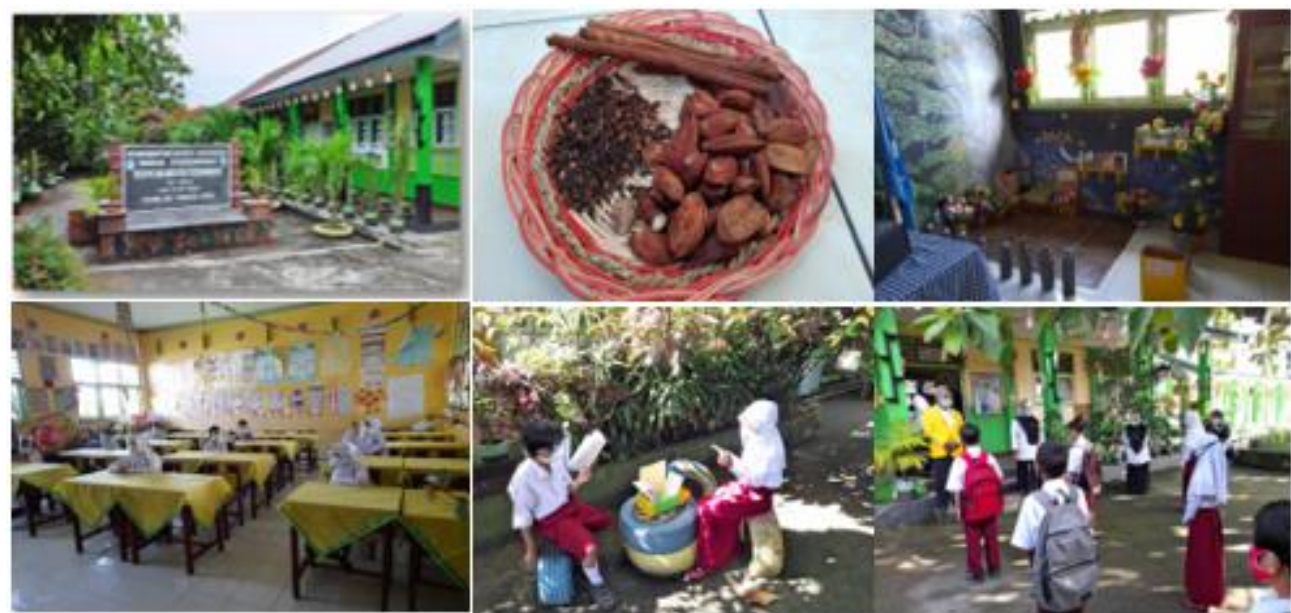

Figure 4. Research Documentation at SDN 50 Ternate City with Ethnopedagogy Implementation.

The results of applying the ethnopedagogic approach to the integration of cloves in science learning for fourth grade students at SDN 50 Ternate city indicate that the goal learning of integrated thematic learning design using the cultural identity of the North Maluku Spice Island as Ternate Cultural Wisdom shows that students are proud of Ternate cultural wisdom needs to be improved.

The ethnopedagogic approach gives the impression given to students in learning using cloves as a North Maluku spice in thematic learning, showing that during the implementation of learning, they feel learning with tension and theory but learning real life every day and comfortable. However, when the teacher provides follow-up in the form of final reflection activities, students are only able to respond and answer the history and benefits of cloves correctly, so it can be concluded that there is a need for stimulation of the integration of local culture in learning in schools through an ethnopedagogic approach.

\section{Conclusion}

The ethnopedagogic approach at SDN 50 Ternate City can be implemented using North Maluku cloves and spices as issues and teaching materials in science subjects. The ethnopedagogic approach can be integrated with the problem-based learning model to provide early knowledge about the cultural identity of North Maluku and cloves as spices. Students' responses to the implementation of learning with an ethnopedagogic approach are happy and motivated to learn science, especially cloves as spices.

\section{Acknowledgment}

The authors would like to thank the LPPM Khairun University of Ternate which has provided a Postgraduate Grant for the 2020 fiscal year for the implementation of this research.

\section{References}

Holbrook Jack. (2009). “The Meaning of Scientific Literacy”. International Journal of Environmental \& Science Educational, 4 (3), 144-150 
Kistanto, N. H. (2015). About the concept of culture. Word: Jurnal Kajian Kebudayaan, 10(2).

Koentjaraningrat. (1974). Culture, Mentalitet, and Development: A Potpourri. Jakarta: Gramedia.

Kun, P. Z. (2013, September). Science learning based on local wisdom. In Proceedings: seminar nasional fisika dan pendidikan fisika (Vol. 4, No. 1).

Maulidia, L., Suwono, H., \& Furaidah, F. (2018). Perception of Biology Education Study Program Lecturers on the Integration and Implementation of Scientific Literacy Components in Curriculum Design. Jurnal Pendidikan: Teori, Penelitian, dan Pengembangan, 3(9), 1115-1121.

Nofiana, M., \& Julianto, T. (2018). Efforts to Improve Students' Scientific Literacy Through Learning Based on Local Excellence. Biosfer: Jurnal Tadris Biologi,, 9(1), 24-35.

Oktavianti, I., \& Ratnasari, Y. (2018). Ethnopedagogy in Learning in Elementary Schools Through Media Based on Local Wisdom. Refleksi Edukatika: Jurnal Ilmiah Kependidikan, 8(2).

Putra, P. (2017). Ethnopedagogical Approach in Science Learning SD/MI. Primary Education Journal (PEJ), 1(1), 17-23.

Rachman, M. 2015. 5 Research Approaches: Quantitative, Qualitative, Mixed, CAR and $R \& D$. Yogyakarta: Magnum Main Library.

Rahmawati, Y., Ridwan, A., Faustine, S., Syarah, S., Ibrahim, I., \& Mawarni, P. C. (2020). Development of Scientific Literacy and Student Cultural Identity Through EthnoPedagogical Approach in Science Learning. Edusains, 12(1), 54-63.

Sartini. 2010. Exploring the Local Wisdom of the Archipelago: A Study of Philosophy. Jurnal Filsafat, 14(2): 111-120.

Sugiyono, (2014). Combined Research Methods (Mixed Methods), Bandung: Alfabeta.

Sugiyono, (2015). Quantitative And Qualitative Research Methods And R\&D. Bandung. Publisher: CV Alfa Beta.

Sularso, S. (2015). Revitalization of local wisdom in basic education. Ahmad Dahlan's Jurnal Pendidikan Sekolah Dasar Ahmad Dahlan, 2(1), 73-80.

Syaban, M. F., \& Wilujeng, I. (2016). Development of local excellence-based substance and energy SSP to increase scientific literacy and environmental awareness. Jurnal Inovasi Pendidikan IPA, 2(1), 66-75.

Tilaar, H.A.R. 2015. Theoretical Pedagogy for Indonesia. Jakarta: Compass Book. 
Utari, U., \& Degeng, I. N. S. (2017). Thematic learning based on local wisdom in elementary schools in the face of the Asean Economic Community (MEA). Jurnal Teori dan Praksis Pembelajaran IPS, 1(1), 39-44.

Wijaya, E. Y., Sudjimat, D. A., Nyoto, A., \& Malang, U. N. (2016). The transformation of 21 st century education as a demand for human resource development in the global era. In Prosiding Seminar Nasional Pendidikan Matematika (Vol. 1, No. 26, pp. 263278).

Yuliati, Y. (2017). Scientific literacy in science learning. Jurnal Cakrawala Pendas, 3(2). 